\title{
Effects of different feed type exposure in early life on performance, rumen fermentation, and feed preference of dairy calves
}

\author{
J. X. Xiao, L. Y. Guo, G. M. Alugongo, Y. J. Wang, Z. J. Cao, and S. L. Li ${ }^{1}$ \\ State Key Laboratory of Animal Nutrition, Beijing Engineering Technology Research Center of Raw Milk Quality and Safety Control, \\ College of Animal Science and Technology, China Agricultural University, Beijing 100193, P. R. China
}

\begin{abstract}
The aim of the study was to evaluate the effects of early feed exposure (EFE) to different feedstuffs in dairy calves on feed preference once fed a free-choice diet and a total mixed ration later in life. Thirty (30) female Holstein calves were randomly assigned at birth to 1 of $3 \mathrm{EFE}$ treatments - concentrate only (CON), hay only $(\mathrm{HO})$, and concentrate and hay $(\mathrm{COH})$ - from d 2 to 56. After that, all calves were offered both concentrate and hay in different buckets from d 57 to 70 to allow them free choice between the 2 feedstuffs. Calves were then transferred to a heifer barn, housed within treatment in pairs ( 2 calves/pen), and fed TMR from $\mathrm{d}$ 71 to 196 . Feed intake was recorded daily from d 2 to 70 to determine the feed preference before and after weaning. Fresh TMR and orts were collected daily in the last week of the experiment (d 190 to 196) for analysis of feed sorting and intake. Body weight and structural growth were recorded at d 1, 28, 56, 70, and 190. Blood for determining glucose and rumen fluid for determining ruminal $\mathrm{pH}$ and volatile fatty acids concentrations were sampled on d 28, 56, 70, and 190. Early feed exposure did not affect feed intake, body weight, average daily gain, blood glucose, and structural growth before and after weaning but did affect feed preference and rumen fermentation. After transition to a free-choice diet, HO calves consumed more hay $(550.2 \mathrm{~g} / \mathrm{d})$ than CON $(177.4 \mathrm{~g} / \mathrm{d})$ and $\mathrm{COH}(396.4 \mathrm{~g} / \mathrm{d})$ calves on the first day only. However, $\mathrm{COH}$ calves consumed a greater amount of hay, resulting in a higher ratio of hay to total solids compared with either CON or HO calves during $\mathrm{d} 57$ to 70 . Upon transition to a TMR, a similar sorting pattern was exhibited between treatments, with calves sorting against the long and for the fine particle fractions. Although no significant long-term effects of different EFE on rumen $\mathrm{pH}$, volatile fatty acids, and blood glucose persisted at wk 27 (from d 190 to 196),
\end{abstract}

Received January 1, 2018.

Accepted April 28, 2018.

${ }^{1}$ Corresponding author: lisheng0677@163.com calves exposed to $\mathrm{COH}$ early had an improved ability to sort for long feed particles compared with CON and $\mathrm{HO}$ calves later in life. Our results suggest that EFE could influence choice of feed immediately after weaning and may have long-lasting effects on feed preference in heifers later in life. Further studies with more calves are recommended.

Key words: dairy calf, feed preference, early experience

\section{INTRODUCTION}

Dairy cows acquire nutrients from plant-based feed through rumen fermentation before digestion. Hay and cereal grains are the commonly used feedstuffs. Hay, high in fiber, can stimulate rumination and is used as a primary source of nutrients. Cereal grains, high in starch, are key components of diets that supply and meet the energy needs of dairy cattle. Cows tend to sort out for concentrates such as grains in a mixed ration (Leonardi and Armentano, 2003). When offered rations containing grain concentrate and hay either separately or in top-dressing hay with concentrate, heifers tended to rapidly consume the grain concentrate in very few large meals first followed by the hay portion (Devries and von Keyserlingk, 2009). Cows are highly sensitive to sweet taste with a high positive hedonic value (Ginane et al., 2011), probably because sweetness reflects the presence of caloric sugars. To encourage the consumption of an adequate, balanced, and complete diet and ensure rumen health, it is a common practice to provide a TMR that has a blend of a variety of feedstuffs. However, the sorting of TMR by dairy cows can lead to an unbalanced nutrient intake with higher grains and lesser forage intake, leading to reduced rumen $\mathrm{pH}$ and, consequently, SARA (Gao and Oba, 2014).

To abate the sorting behavior in herds on the farm, previous studies have explored strategies, including nutritional (Leonardi and Armentano, 2003; Devries et al., 2007) and feeding (Devries et al., 2005; Hart et al., 2014) management. These strategies, though geared toward preventing the sorting behavior, might not fully address the issue of preference for certain feedstuffs. In 
human studies, selecting food (equivalent of sorting in animals) has been reported in both children and adults. Scientists have argued that the most salient way to modify food preference in children might involve early exposure to both the taste and texture of different foods in the preweaning period and, hence, acceptance of diverse food patterns (Harris, 2008; Cooke and Fildes, 2011). Similarly, a growing body of evidence has shown that experiences early in life may influence the learning and development of feeding behavior in cows (MillerCushon et al., 2013; Miller-Cushon and Devries, 2017). Further research is required to explore whether early feed exposure (EFE) experience might affect the selection against or for certain feeds postweaning of calves and subsequent reduction in feed sorting later in life.

It is generally accepted that starter (concentrate) and hay (forage) are important feedstuff for calves during the preweaning period. Several studies have investigated whether forage should be provided before weaning by observing performance and health of calves (Suarez-Mena et al., 2016; Imani et al., 2017). However, studies exploring EFE during the milk-feeding period on postweaning feed selection and how it contributes to sorting behavior in heifers are scarce. Therefore, the aim of this study was to investigate the effects of feeding different types of feed in early life on feed preference postweaning and to examine whether sorting behavior would be minimized when calves have matured. We hypothesized that calves would prefer to select for the feed components to which they had been exposed early in life. Second, we hypothesized that differences in feed preference early in life would last up to 6 mo.

\section{MATERIALS AND METHODS}

\section{Animals and Feeding}

This study was conducted at the Modern Farming Co. Ltd. (Baoji, Shanxi, P. R. China). A priori statistical power analysis (SAS PROC POWER, SAS Institute Inc., Cary, NC) using primary response variables, DMI, and ADG was done to determine whether the number of animals per treatment was adequate. Based on previous results (Miller-Cushon and DeVries, 2011; Castells et al., 2013) and using $\alpha=0.05$ and power $=$ 0.80 , the projected sample size was approximately 9 calves for DMI and 27 calves for ADG in total. Thus, we projected that a sample size of 30 calves was more than sufficient to investigate our main objectives in this study. Thirty (30) female Holstein calves were separated from their dams immediately after birth and fed $4 \mathrm{~L}$ of colostrum within $1 \mathrm{~h}$ of birth. Body weight and serum total protein were measured on $\mathrm{d} 2$. Selected calves (initial BW $=38.2 \pm 2.1 \mathrm{~kg}$; serum total protein $\geq 5.5 \mathrm{~g} / \mathrm{dL}$ ) were kept in individual hutches with free access to solid feed and water from d 2. Two buckets containing solid feed were hung inside the hutch, and another 2 buckets for water and milk were attached on the outside and in front of the hutch. Sand was used as the bedding material and was replenished every 2 wk. The calves were fed milk twice daily at 0800 and 1600 $\mathrm{h}$ from d 2 to 56 , consisting of $6 \mathrm{~L} / \mathrm{d}$ from d 2 to 14,8 $\mathrm{L} / \mathrm{d}$ from d 15 to $42,6 \mathrm{~L} / \mathrm{d}$ from d 43 to 49 , and $4 \mathrm{~L} / \mathrm{d}$ afterward until weaning on d 56. Milk was pasteurized using a milk pasteurizer, where milk temperature was elevated and held at $60^{\circ} \mathrm{C}$ for $30 \mathrm{~min}$ and then cooled to $37^{\circ} \mathrm{C}$. All calves were weaned on d 56 and remained in the hutch until $\mathrm{d} 70$. Thereafter, the calves were transferred to a barn and housed within treatment in pairs $(2$ calves/pen; $\mathrm{n}=15)$. The pens consisted of a sawdust-bedded pack area and a feed lane equipped with an automatic cable scraping system. The bedding material was renewed on weekly basis. Feed bunks were located in front of the lane. The calves had free access to feed and water in each pen.

\section{Experimental Design and Diets}

From d 2 to 56 , calves were randomly assigned to 1 of 3 feed exposure treatments: concentrate only (CON), hay only $(\mathrm{HO})$, and concentrate and hay $(\mathrm{COH})$. The calves remained on their respective solid feed type throughout the milk-feeding stage (d 2-56). Postweaning, all 30 female calves were offered 2 types of feed (concentrate and hay in different buckets) for $14 \mathrm{~d}(\mathrm{~d}$ 57-70) to allow calves free access to either concentrate or hay. Calves were then fed TMR from d 71 to 196.

Starter grain (Modern Farming Co. Ltd., Baoji, Shanxi, P. R. China; Table 1) and mixed hay (50:50 alfalfa and oat hay at $<2.5 \mathrm{~cm}$; Table 1) were offered every morning for ad libitum intake. To avoid any bias in preference, the concentrate and hay feeds were each evenly divided into 2 parts and subsequently added to the feeding buckets for calves fed $\mathrm{CON}$ and $\mathrm{HO}$, respectively. For $\mathrm{COH}$ calves, the position of the concentrate and hay feed buckets was alternated on a daily basis. Fresh TMR (Table 1) was fed once daily at $1000 \mathrm{~h}$ immediately after orts disposal. Feed offered was adjusted daily to ensure at least $10 \%$ orts. The actual percentage of orts was similar among treatments $(\mathrm{CON}=17.8 \%$, $\mathrm{HO}=17.2 \%, \mathrm{COH}=15.9 \% ; \mathrm{SE}=1.1 \%, P=0.46)$.

\section{Feed Sampling and Analysis}

Throughout the study, daily feed intake was recorded based on the amount offered and refused by 
each calf from d 2 to 70 . Upon transition to TMR, feed intake was calculated by each pen in the last week of the experiment (d 190-196). Representative samples of concentrate and hay were collected weekly and for TMR in the last week of the experiment (wk 28). All samples were immediately frozen at $-20^{\circ} \mathrm{C}$ until they were further analyzed for nutritional composition. Dry matter, $\mathrm{CP}, \mathrm{NDF}, \mathrm{ADF}$, ether extract, and ash were analyzed following the methods of AOAC International (1995). The nutritional composition of all diets is listed in Table 1.

\section{Feed Preference and Sorting Analysis}

Feed intake ratio (FIR) was calculated based on hay intake divided by TS feed (including concentrate and hay) intake for calves fed $\mathrm{COH}$ only from d 2 to 56 and for all calves from d 57 to 70 . The DMI and FIR data were calculated and analyzed for individual calves to determine the feed preference before and after weaning. In wk 28 (from d 190-196), sorting behavior was analyzed using samples of fresh TMR offered and orts collected daily per pen $(\mathrm{n}=5)$. Fresh feed and orts samples were taken from each of the feed bunks immediately after delivery of new TMR and $22 \mathrm{~h}$ after feeding, respectively. Samples were separated into 4 fractions (Maulfair et al., 2011) based on the particle size (long: $>19 \mathrm{~mm}$; medium: $<19$ and $>8 \mathrm{~mm}$; short: $<8$ and $>4$

Table 1. Nutrient composition (\% DM basis) of concentrate, hay, and $\mathrm{TMR}^{1}$

\begin{tabular}{lrrr}
\hline $\begin{array}{l}\text { Nutrient } \\
\text { composition }\end{array}$ & $\mathrm{CON}^{2}$ & $\mathrm{HO}^{3}$ & $\mathrm{TMR}^{4}$ \\
\hline $\mathrm{DM}$ & 88.6 & 88.3 & 56.0 \\
$\mathrm{CP}$ & 19.2 & 12.9 & 13.6 \\
$\mathrm{NDF}$ & 15.4 & 46.5 & 36.0 \\
$\mathrm{ADF}$ & 5.9 & 22.5 & 20.4 \\
Ash & 5.8 & 8.6 & 12.8 \\
Ether extract & 3.3 & 2.8 & 3.0 \\
\hline
\end{tabular}

${ }^{1}$ Calves were exposed to concentrate (CON), hay (HO), or concentrate and hay $(\mathrm{COH})$ during the preweaning period (d 2-56). After weaning, all calves were exposed to concentrate and hay (d 57-70), and then TMR was supplied from d 71 to 196.

${ }^{2}$ Concentrate starter (Modern Farming Co. Ltd., Baoji, Shanxi, P. R. China). Contained $36 \%$ corn, $10 \%$ wheat bran, $25 \%$ rolled barley, $16 \%$ soybean meal, $8 \%$ canola meal, $1.5 \%$ sodium bicarbonate, $0.5 \%$ premix compound, $1 \%$ sodium chloride, and $2 \%$ molasses on an as-fed basis.

${ }^{3} 50 \%$ alfalfa and $50 \%$ oat grass was mixed and cut to a length of $<2.5$ cm using a stationary mixer $\left(20 \mathrm{~m}^{3}\right.$, Trioliet Co. Ltd., Oldenzaal, the Netherlands). According to the Penn State Particle Separator (Kononoff et al., 2003), chopped hay $(<2.5 \mathrm{~cm})$ contained $30.9 \%$ long ( $>19 \mathrm{~mm}), 28.4 \%$ medium $(<19$ and $>8 \mathrm{~mm}), 25.2 \%$ short $(<8$ and $>4 \mathrm{~mm})$, and $15.5 \%$ fine $(<4 \mathrm{~mm})$ particles.

${ }^{4}$ Contained steam-flaked corn $(31.1 \%)$, alfalfa hay $(22.6 \%)$, oat hay (22.6\%), soybean meal (19.3\%), and premix compound $(0.4 \%)$ on a DM basis. The TMR contained $11.7 \%$ long, $30.8 \%$ medium, $26.7 \%$ short, and $30.8 \%$ fine particles. $\mathrm{mm}$; fine: $<4 \mathrm{~mm})$ particles using a 3 -sieve $(19,8$, and $4 \mathrm{~mm}$ ) Penn State Particle Separator (PSPS; Kononoff et al., 2003). Sorting was calculated as the actual intake of each fraction expressed as a percentage of the predicted intake of that fraction. The actual intake of each individual fraction was calculated as the difference between the as-fed amount of each fraction in the feed offered and that in the orts. The predicted intake for an individual fraction was calculated as the product of the as-fed intake of the total diet multiplied by the as-fed percentage of that fraction in the TMR (Leonardi and Armentano, 2003). Values greater than 100\% indicate preferential consumption (sorting for), values less than $100 \%$ indicate selective refusals (sorting against), and values equal to $100 \%$ indicate no sorting. The daily data were summarized for each pen during wk 28 before analysis.

\section{BW and Structural Measurements}

All calves were weighed every $2 \mathrm{wk}$ for the first $10 \mathrm{wk}$ (d 1, 28, 56, 70) and then weighed on wk 28 (d 190). Body length, withers height, hip width, and heart girth were also recorded at these time points. Only crucial time points (d 1, 56, 70, 190) were listed in the study.

\section{Blood and Rumen Samples}

Blood was sampled before the morning feeding on $\mathrm{d}$ 28, 56, 70, and 190 to determine glucose. Briefly, blood was collected via the jugular vein using evacuated tubes containing no anticoagulant for serum separation. Blood was then centrifuged at 3,500 $\times g$ for 15 min at $4^{\circ} \mathrm{C}$ for separation of serum. An aliquot of the serum was used to determine serum total protein by optical refractometer (Honneur Nutritional Technology Co. Ltd., Beijing, P. R. China). Whole blood was collected to test glucose concentration using a hand-held glucometer (model 580, Yuwell Co., Jiangsu, P. R. China). Rumen fluid was collected on d 28, 56, 58, 63, 70, and 190 of age via a flexible esophageal tube $(2 \mathrm{~mm}$ wall thickness, 6 mm i.d.; Anscitech Co. Ltd., Wuhan, Hubei, P. R. China) from all calves $2 \mathrm{~h}$ after the morning feeding. Rumen $\mathrm{pH}$ was measured immediately with a glass electrode $\mathrm{pH}$ meter. Fifteen milliliters of rumen fluid was preserved at $-20^{\circ} \mathrm{C}$ for later analysis of VFA (Erwin et al., 1961).

\section{Statistical Analyses}

Before d 70 when calves were fed in the hutches, data for ADG and DMI were summarized for each calf by week and analyzed separately by time period (d 2-28, 
Table 2. Effect of early feed exposure on total DMI ( $\mathrm{g} / \mathrm{d}$, including concentrate and hay DMI) in calves $(\mathrm{n}=$ 10 females/treatment) before and after weaning off milk

\begin{tabular}{|c|c|c|c|c|c|c|c|}
\hline \multirow[b]{2}{*}{ Period } & \multicolumn{3}{|c|}{ Treatment $^{1}$} & \multirow[b]{2}{*}{ SEM } & \multicolumn{3}{|c|}{$P$-value } \\
\hline & $\mathrm{CON}$ & $\mathrm{HO}$ & $\mathrm{COH}$ & & $\begin{array}{c}\text { CON } \\
\text { vs. HO }\end{array}$ & $\begin{array}{c}\mathrm{CON} \\
\text { vs. } \mathrm{COH}\end{array}$ & $\begin{array}{c}\mathrm{HO} \\
\text { vs. } \mathrm{COH}\end{array}$ \\
\hline Day 2-28 (g/d) & 34.1 & 5.65 & 23.9 & 7.38 & 0.02 & 0.56 & 0.21 \\
\hline Day $29-56(\mathrm{~g} / \mathrm{d})$ & 173.5 & 159.4 & 190.6 & 26.7 & 0.93 & 0.89 & 0.69 \\
\hline Day $57-70(\mathrm{~g} / \mathrm{d})$ & $1,624.1$ & $1,680.9$ & $1,568.1$ & 105.8 & 0.93 & 0.93 & 0.74 \\
\hline Day $190-196(\mathrm{~kg} / \mathrm{d})$ & 5.63 & 5.65 & 5.83 & 0.25 & 0.99 & 0.84 & 0.87 \\
\hline
\end{tabular}

d 29-56, and d 57-70). Data for FIR were summarized for each calf by week and analyzed separately by stage of life (preweaning, d 2-56; postweaning, d 57-70) and were additionally analyzed for each calf by day from $\mathrm{d}$ 57 to 70 to test the treatment, time, and treatment $\times$ time effects. Data for BW and structural growth were summarized for each calf at d 1, 28, 56, 70, and 190. Data for glucose were summarized for each calf at d 28 , 56, 70, and 190, and data for $\mathrm{pH}$ and VFA were summarized for each calf at d 28, 56, 58, 63, 70, and 190. All data were analyzed using the MIXED procedure of SAS (SAS Institute Inc., Cary, NC) with time as a repeated measure. The model included the fixed effects of time, treatment, and time $\times$ treatment interaction and the random effect of calf within treatment. Calf was the experimental unit.

After transition to group feeding, all continuous daily data (e.g., DMI and each PSPS fraction) were averaged to a single measurement for each pen. Pen was the experimental unit. These data were also analyzed using the MIXED procedure of SAS (SAS Institute
Inc.), treating day from d 190 to 196 as a repeated measure. The model included the fixed effects of day, treatment, and day $\times$ treatment interaction and the random effect of pen within treatment. For all analyses, significant differences were declared at $P \leq 0.05$, with trends indicated at $0.05<P \leq 0.10$.

\section{RESULTS AND DISCUSSION}

\section{Feed Intake and Performance}

During the milk-feeding period (d 1-56), calves consumed all the milk offered to them daily and were exposed to different types of feed. Dry matter intake, BW, and ADG are shown in Tables 2 and 3. Calves exposed early to concentrate had greater DMI than calves offered only hay during d 2 to $28(P=0.02)$, but no treatment effect was found in other periods. However, DMI increased as calves grew older and increased more rapidly from d 56 when milk was withdrawn $(P$ $=0.001$; data not shown $)$. Body weight was similar be-

Table 3. Effect of early feed exposure on BW and ADG in calves ( $\mathrm{n}=10$ females/treatment) before and after weaning off milk

\begin{tabular}{|c|c|c|c|c|c|c|c|}
\hline \multirow[b]{2}{*}{ Item } & \multicolumn{3}{|c|}{ Treatment $^{1}$} & \multirow[b]{2}{*}{ SEM } & \multicolumn{3}{|c|}{$P$-value } \\
\hline & $\mathrm{CON}$ & $\mathrm{HO}$ & $\mathrm{COH}$ & & $\begin{array}{c}\text { CON } \\
\text { vs. HO }\end{array}$ & $\begin{array}{c}\mathrm{CON} \\
\text { vs. } \mathrm{COH}\end{array}$ & $\begin{array}{c}\mathrm{HO} \\
\text { vs. } \mathrm{COH}\end{array}$ \\
\hline \multicolumn{8}{|l|}{$\overline{\mathrm{BW}(\mathrm{kg})}$} \\
\hline Day 1 & 38.2 & 38.3 & 38.2 & 0.69 & 0.99 & 1.00 & 1.00 \\
\hline Day 28 & 59.7 & 60.3 & 60.0 & 0.98 & 0.93 & 0.97 & 0.99 \\
\hline Day 56 & 81.7 & 83.1 & 82.9 & 1.22 & 0.70 & 0.78 & 0.99 \\
\hline Day 70 & 93.5 & 92.9 & 93.7 & 1.62 & 0.96 & 0.99 & 0.92 \\
\hline Day 190 & 224.4 & 223.6 & 227.9 & 5.04 & 0.40 & 0.88 & 0.71 \\
\hline \multicolumn{8}{|l|}{$\mathrm{ADG}(\mathrm{kg} / \mathrm{d})$} \\
\hline Day $1-28$ & 0.77 & 0.79 & 0.78 & 0.02 & 0.87 & 0.93 & 0.99 \\
\hline Day $29-56$ & 0.78 & 0.82 & 0.81 & 0.03 & 0.72 & 0.73 & 0.99 \\
\hline Day $57-70$ & 0.87 & 0.71 & 0.79 & 0.08 & 0.32 & 0.73 & 0.75 \\
\hline Day $71-190$ & 1.10 & 1.18 & 1.12 & 0.04 & 0.27 & 0.94 & 0.47 \\
\hline
\end{tabular}

${ }^{1}$ During the preweaning period (d 2-56), calves were offered concentrate only (CON), hay only (HO), or both concentrate and hay $(\mathrm{COH})$. After weaning, all calves were exposed to concentrate and hay $(\mathrm{d} 57-70)$, and then TMR was supplied from d 71 to 196. 
tween treatments on $\mathrm{d} 1,28,56$, and 70 and at the end of the experiment. Likewise, ADG was not influenced by treatment during the preweaning (d 1-28 and $\mathrm{d}$ 29-56) or postweaning (d 57-70 and d 71-196) periods.

Calves that were offered only hay preweaning consumed a negligible amount of hay $(6 \mathrm{~g} / \mathrm{d})$ before d 28 , which was lower compared with calves offered CON $(34.1 \mathrm{~g} / \mathrm{d}, P=0.02)$. Hay is bulkier than concentrate and is more likely to fill the rumen faster. Moreover, in the early weeks of life, newborn calves are monogastric with a small and nonfunctional rumen (Stobo et al., 1966), which might result in limited intake of solid feed, especially hay.

It is well documented that the proportion of concentrate to hay could affect the BW and ADG of calves (Miller-Cushon and Devries, 2011; Castells et al., 2013). A higher proportion of concentrate in the diet is likely to increase $\mathrm{BW}$ as a result of greater nutrient intake (Stobo et al., 1966). However, surprisingly, in the present study calves offered $\mathrm{HO}$ had similar performance (BW and ADG) to those offered CON. The average DMI was very low before weaning on d $56(\mathrm{CON}$ : 0.10 $\mathrm{kg} / \mathrm{d}$; HO: $0.08 \mathrm{~kg} / \mathrm{d}$; $\mathrm{COH}: 0.11 \mathrm{~kg} / \mathrm{d} ; P=0.70$, data not shown) in the current study compared with the study of Castells et al. (2013), who fed their calves a total of $212 \mathrm{~L}$ and $0.60 \mathrm{~kg}$ of $\mathrm{DM} / \mathrm{d}$ during the milkfeeding period. However, our calves consumed higher volumes of milk (378 L), which might have contributed to the lower DMI (Alugongo et al., 2017), hence masking the effects of EFE experience that is positively associated with BW and ADG (Stobo et al., 1966).

\section{Feed Preference and Sorting Analysis}

During d 2 to 56, calves exposed to concentrate early had higher starter intake $(103.8 \mathrm{~g} / \mathrm{d})$ than those exposed to $\mathrm{COH}(66.4 \mathrm{~g} / \mathrm{d} ; P=0.13$; Table 4$)$. Likewise, calves fed HO consumed higher amounts $(82.5 \mathrm{~g} / \mathrm{d})$ of hay compared with those fed $\mathrm{COH}(40.8 \mathrm{~g} / \mathrm{d} ; P<$ 0.01). Calves in the $\mathrm{COH}$ group consumed almost half hay (accounting for $45 \%$ of TS intake) and half concentrate $(55 \%)$ during the same period. Following transition to the free-choice feed (d 57-70), no differences were found between $\mathrm{CON}$ and $\mathrm{HO}$ groups, with calves consuming similar amounts of concentrates (1,374 vs. $1,424 \mathrm{~g} / \mathrm{d} ; P=0.96)$ and hay $(250$ vs. $256 \mathrm{~g} / \mathrm{d} ; P=$ $0.99)$, which translated to similar ratio of hay to TS (17.7 vs. $16.5 \%, P=0.97$ ) in the 2 groups (Table 4 ). In contrast to our results, Miller-Cushon and Devries (2011), who evaluated the effect of EFE experiences on feed preference, demonstrated that dairy calves exposed to either hay or concentrate before weaning sorted a mixed diet in favor of the feed components they were familiar with at least up to $4 \mathrm{wk}$ postweaning. To gain a deeper understanding of this phenomenon, we analyzed the data on feed preference by day instead of by week. Interestingly, we found that calves exposed to hay early exhibited a tendency toward a higher ratio of hay to TS compared with calves that were exposed to concentrate only $(52.1 \%$ vs. $30.8 \% ; P=0.10)$ on the first day after weaning (Figure 1), mostly due to higher hay consumption (550.2 vs. $177.4 \mathrm{~g} / \mathrm{d} ; P<0.01$; Figure 2). Similar observations were made by Miller-Cushon and Devries (2011). Young calves can establish a preference for a familiar feed type and will initially be hesitant to consume a novel feedstuff (Costa et al., 2014; MillerCushon and Devries, 2017). On d 2 postweaning, the amount of hay consumed decreased rapidly in the HO group, and calves in this group began to consume more concentrate (Figures 2 and 3). No prolonged effects of feed preference were found between $\mathrm{CON}$ and $\mathrm{HO}$ calves. The differences in effects of early experience on feed preference in the current study compared with Miller-Cushon and Devries (2011) could be attributed

Table 4. Effect of early feed exposure on total DMI (including concentrate and hay DMI) and feed intake ratio of hay to TS in calves $(\mathrm{n}=10$ females/treatment) before and after weaning off milk

\begin{tabular}{|c|c|c|c|c|c|c|c|}
\hline \multirow[b]{2}{*}{ Item } & \multicolumn{3}{|c|}{ Treatment $^{1}$} & \multirow[b]{2}{*}{ SEM } & \multicolumn{3}{|c|}{$P$-value } \\
\hline & $\mathrm{CON}$ & $\mathrm{HO}$ & $\mathrm{COH}$ & & $\begin{array}{c}\mathrm{CON} \\
\text { vs. HO }\end{array}$ & $\begin{array}{c}\mathrm{CON} \\
\text { vs. } \mathrm{COH}\end{array}$ & $\begin{array}{c}\mathrm{HO} \\
\text { vs. } \mathrm{COH}\end{array}$ \\
\hline \multicolumn{8}{|l|}{ Day 2-56 DMI } \\
\hline Concentrate $(\mathrm{g} / \mathrm{d})$ & 103.8 & - & 66.4 & 13.2 & - & 0.13 & - \\
\hline Hay $(\mathrm{g} / \mathrm{d})$ & - & 82.5 & 40.8 & 6.01 & - & - & $<0.01$ \\
\hline Hay/TS (\%) & - & - & 45.0 & - & - & - & - \\
\hline \multicolumn{8}{|l|}{ Day 57-70 DMI } \\
\hline Concentrate $(\mathrm{g} / \mathrm{d})$ & $1,374.1$ & $1,423.9$ & $1,069.8$ & 128.4 & 0.96 & 0.23 & 0.14 \\
\hline Hay $(g / d)$ & 250.0 & 256.1 & 498.2 & 53.1 & 0.99 & $<0.01$ & $<0.01$ \\
\hline Hay/TS (\%) & 17.7 & 16.5 & 35.6 & 4.53 & 0.97 & 0.03 & 0.02 \\
\hline
\end{tabular}

${ }^{1}$ During the preweaning period (d 2-56), calves were offered concentrate only (CON), hay only (HO), or both concentrate and hay $(\mathrm{COH})$. After weaning, all calves were exposed to concentrate and hay $(\mathrm{d} 57-70)$, and then TMR was supplied from d 71 to 196. 


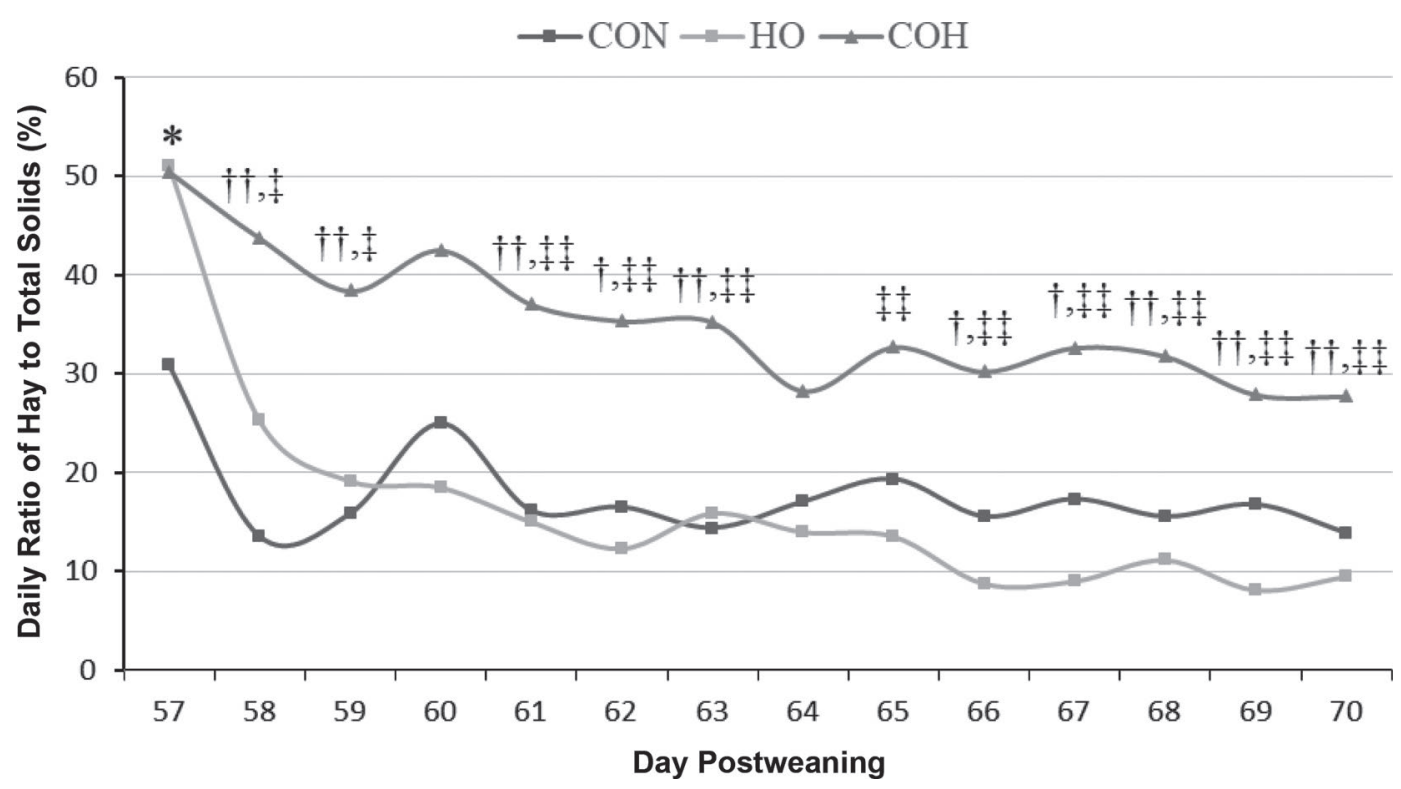

Figure 1. Daily feed intake ratio of hay to TS when concentrate and hay were offered free choice. During the preweaning period (d 2-56), calves were offered concentrate only $(\mathrm{CON})$, hay only $(\mathrm{HO})$, and both concentrate and hay $(\mathrm{COH})$. After weaning, all calves were exposed to concentrate and hay (d 57-70), and then TMR was supplied from d 71 to $196 .{ }^{*} 0.05<P \leq 0.1$ between CON and HO; $\dagger \dagger P \leq 0.05, \dagger 0.05<P$ $\leq 0.1$ between $\mathrm{CON}$ and $\mathrm{COH} ; \ddagger \ddagger P \leq 0.05, \ddagger 0.05<P \leq 0.1$ between $\mathrm{HO}$ and $\mathrm{COH}$.

to the feeding approach used: the latter fed a mixed diet $(60 \%$ forage and $40 \%$ concentrate), whereas we offered concentrate and hay separately with the aim of allowing calves to choose. Alternatively, the short-lived period in selecting between $\mathrm{CON}$ and $\mathrm{HO}$ may have been related to the very low solid feed intake (average: $0.1 \mathrm{~kg} / \mathrm{d}$ ) during the preweaning period limiting the effect of EFE on calves.

Without milk feeding, concentrate became the most popular choice for calves fed earlier on CON (account-

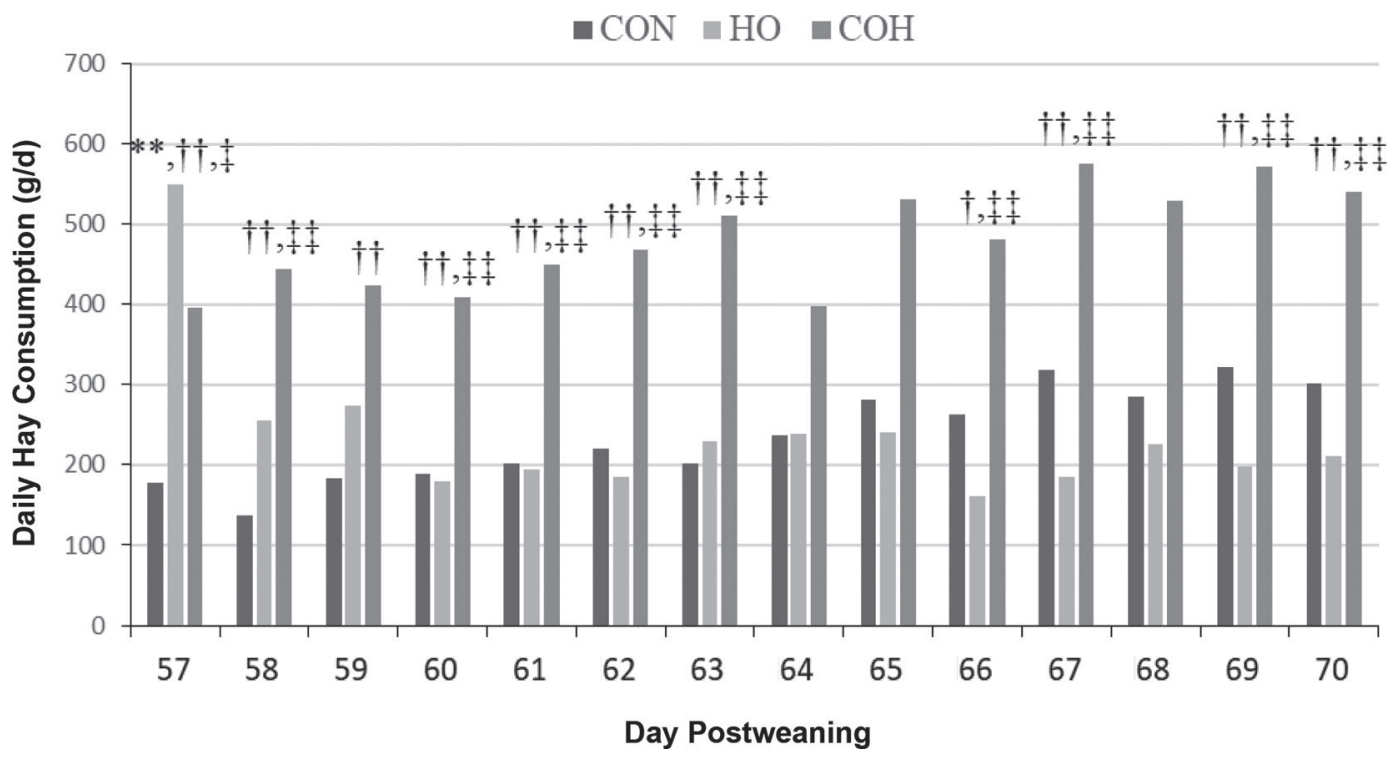

Figure 2. Daily hay consumption when concentrate and hay were offered free choice. During the preweaning period (d 2-56), calves were offered concentrate only $(\mathrm{CON})$, hay only $(\mathrm{HO})$, and both concentrate and hay $(\mathrm{COH})$. After weaning, all calves were exposed to concentrate and hay (d 57-70), and then TMR was supplied from d 71 to 196 . ${ }^{* *} P \leq 0.05$ between CON and HO; $\dagger \dagger P \leq 0.05, \dagger 0.05<P \leq 0.1$ between

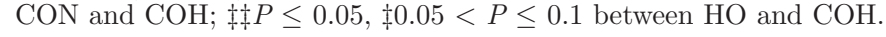


ing for $82.3 \%$ of TS intake), $\mathrm{HO}(83.5 \%)$, and $\mathrm{COH}$ (64.4\%). Given that dairy cows have a strong preference for sweet flavors (Nombekela et al., 1994; Ginane et al., 2011) that reflect higher energy levels in the diet, it is easier to understand why weaned calves consumed a gradually higher percentage of concentrate over time to meet the taste preferences and energy requirements (Figures 1 and 3). Although calves from early exposure to hay could not establish preference for forage, it was unexpected to find that calves exposed to $\mathrm{COH}$ early consumed a higher ratio of hay $(35.6 \%)$ compared with CON $(17.7 \%, P=0.03)$ and HO $(16.5 \%, P=0.02)$ calves as a result of higher hay intake in $\mathrm{COH}$ (Table 4; Figure 2). To our knowledge, this is the first work to note that early exposure to both concentrate and hay might be an effective way to encourage calves to consume more forage postweaning. It is possible that calves fed the $\mathrm{COH}$ diet were accustomed to a certain ratio of hay to concentrate before weaning, which persisted postweaning, and the pattern of selection could not be changed in a short period of time. Similar to our results, Miller-Cushon et al. (2013) claimed that calves previously fed a mixed diet (70\% concentrate and $30 \%$ hay offered as a mixture) sorted in favor of concentrate, whereas calves previously fed concentrate and hay separately did not sort in favor of either feed component after transition to the mixed ration. More research is required to investigate whether consistent results would be found. Furthermore, volume of milk fed might also influence the FIR before and after weaning. For example, Castells et al. (2013) feeding calves concentrate and hay separately with $212 \mathrm{~L}$ of milk resulted in $15 \%$ of hay to TS feed before weaning (d 8-56) and $11 \%$ of hay to TS feed after weaning (d 57-70), which was much lower than $45 \%$ (preweaning) and $35.6 \%$ (postweaning) in the present study where $378 \mathrm{~L}$ milk was fed in similar period. Thus, further research needs to consider the effect of milk volume on feed component selection in calves.

Following transition to TMR, feed sorting was estimated for 7 consecutive days during d 190 to 196 by comparing actual pen-level intakes of various PSPS particle fractions with the predicted intakes. Previous studies illustrated that calves were capable of sorting a TMR (Miller-Cushon et al., 2013; Costa et al., 2016; Overvest et al., 2016). In line with these results, all calves in the present study were sorting against long-particle fractions (average: 98.0\%), which closely represented hay, and for fine particles (average: $104.1 \%$ ), which were primarily concentrate (Table 5). No differences in sorting of each fraction was exhibited among treatments $(P>0.05)$, indicating that the effect of EFE to different feed types during the preweaning period might not have a long-lasting effect on feed selection (sorting behavior), especially between $\mathrm{CON}$ and HO (long: 97.1 vs. $97.7 \%, P=0.85$; medium: 98.1 vs. $98.2 \%, P=0.88$; short: 98.6 vs. $98.3 \%, P=0.45$; fine: 104.3 vs. $104.2 \%, P=0.91)$. These results were similar

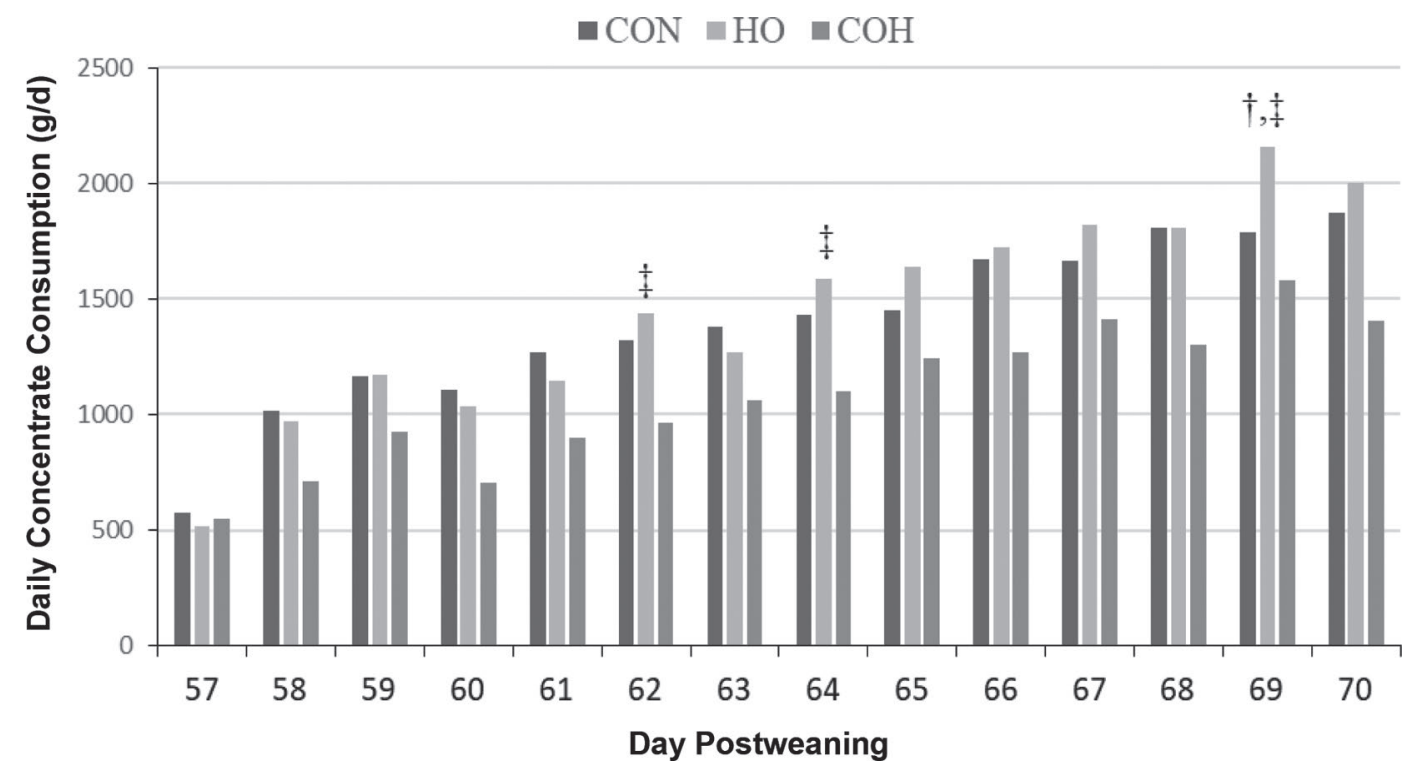

Figure 3. Daily concentrate consumption when concentrate and hay were offered free choice. During the preweaning period (d 2-56), calves were offered concentrate only $(\mathrm{CON})$, hay only $(\mathrm{HO})$, and both concentrate and hay $(\mathrm{COH})$. After weaning, all calves were exposed to concentrate and hay (d 57-70), and then TMR was supplied from d 71 to 196 . $\dagger 0.05<P \leq 0.1$ between CON and COH; $\ddagger 0.05<P \leq 0.1$ between $\mathrm{HO}$ and $\mathrm{COH}$. 
to the findings of Miller-Cushon and Devries (2011), who demonstrated that calves previously exposed to either concentrate or hay sorted for the familiar feed component immediately following transition to the TMR, but after 4 wk calves exhibited a similar sorting pattern. This suggest that early exposure to solely hay may not evoke calves to consume more forage and subsequently reduce the sorting behavior later in life. Our results should be interpreted with caution because calves were grouped after d 70 .

Although no treatment effects for feed sorting behavior were found, calves exposed to both concentrate and hay early in life exhibited numerically higher preference for long particle fractions (99.3\%) than those exposed to concentrate $(97.3 \%, P=0.12)$ or hay $(97.7 \%, P=$ 0.29 ). These numerical differences are noteworthy given that the main purpose of feeding TMR is to encourage the consumption of a balanced ration and prevent sorting. It is more difficult for dairy cows to sort out a TMR compared with a separated feeding diet (DeVries and von Keyserlingk, 2009). Thus, using a TMR (during d 190-196) might minimize the effect of previous EFE compared with feeding forage and concentrate separately (during d 57-70). Besides, feed sorting is an important subject in relation to the physical and chemical characteristics of rations (Miller-Cushon and Devries, 2017), including forage inclusion rate (Devries et al., 2007; Greter et al., 2008), particle size (Leonardi and Armentano, 2003; Nasrollahi et al., 2014), and DM content (Leonardi et al., 2005). These characteristics of rations could influence the degree of feed sorting, which may mask the effects of previous feed exposure. Lack of effects of EFE on later sorting behavior in heifers was not expected due to our assumptions that differences in the preweaning period would persist later in life. A post hoc statistical power analysis for sorting behavior showed that the number of pens $(\mathrm{n}=5)$ used was not sufficient in this study. Further studies with more experimental units are required to determine whether early exposure to both concentrate and hay fed separately could regulate feed sorting later in life under different feeding conditions.

\section{Structural Measurements}

Most of the structural measurements, including withers height, body length, and heart girth, were similar throughout the experiment (Table 6), probably due to the similar DMI and volumes of milk consumed (Khan et al., 2007). Early exposure to hay could have enlarged abdominal girth in the current study, as calves fed HO had higher abdominal girth $(100.2 \mathrm{~cm}, P=0.04)$ than calves assigned to CON $(94.7 \mathrm{~cm})$ at weaning (d 56). Similarly, Nemati et al. (2016) demonstrated that supplementation of grass hay in calves' diet linearly increased abdominal girth. Because hay is a more bulky feed than concentrates, an increase in rumen volume (Stobo et al., 1966) as a result of feeding hay probably enlarged abdominal girth. When concentrate and hay were both offered ad libitum from d 56, no differences in abdominal girth were reported among treatments at d 70 .

\section{Glucose and Rumen Fermentation}

The least squares means for concentrations of glucose are shown in Table 7. Blood glucose was within the normal ranges reported in the literature (Wijayasinghe et al., 1984). No treatment or time $\times$ treatment interaction effects were found throughout the experiment. A time effect was observed on glucose $(\mathrm{d} 28=6.64 \mathrm{mmol} / \mathrm{L}$, d $56=5.16 \mathrm{mmol} / \mathrm{L}$, and $\mathrm{d} 70=3.75 \mathrm{mmol} / \mathrm{L} ; \mathrm{n}=30$; $P<0.001$ ), which was consistent with previous findings (Khan et al., 2011; Nemati et al., 2016). Glucose is the primary energy substrate for calves due to the limited utilization of VFA in undeveloped rumen epithelium

Table 5. Effect of early feed exposure on sorting (\%) of each particle size fraction during d 190 to $196^{1}$

\begin{tabular}{|c|c|c|c|c|c|c|c|}
\hline \multirow[b]{2}{*}{$\begin{array}{l}\text { Particle } \\
\text { size }^{2}\end{array}$} & \multicolumn{3}{|c|}{ Treatment $^{3}$} & \multirow[b]{2}{*}{ SEM } & \multicolumn{3}{|c|}{$P$-value } \\
\hline & $\mathrm{CON}$ & $\mathrm{HO}$ & $\mathrm{COH}$ & & $\begin{array}{c}\text { CON } \\
\text { vs. HO }\end{array}$ & $\begin{array}{c}\mathrm{CON} \\
\text { vs. } \mathrm{COH}\end{array}$ & $\begin{array}{c}\mathrm{HO} \\
\text { vs. } \mathrm{COH}\end{array}$ \\
\hline Long & 97.1 & 97.7 & 99.3 & 0.76 & 0.85 & 0.12 & 0.29 \\
\hline Medium & 98.1 & 98.2 & 98.0 & 0.11 & 0.88 & 0.67 & 0.38 \\
\hline Short & 98.6 & 98.3 & 98.1 & 0.16 & 0.45 & 0.19 & 0.83 \\
\hline Fine & 104.3 & 104.2 & 103.9 & 0.14 & 0.91 & 0.15 & 0.31 \\
\hline
\end{tabular}


Table 6. Effect of early feed exposure on structural growth in calves ( $\mathrm{n}=10$ females/treatment) before and after weaning off milk

\begin{tabular}{|c|c|c|c|c|c|c|c|}
\hline \multirow[b]{2}{*}{ Item } & \multicolumn{3}{|c|}{ Treatment $^{1}$} & \multirow[b]{2}{*}{ SEM } & \multicolumn{3}{|c|}{$P$-value } \\
\hline & $\mathrm{CON}$ & $\mathrm{HO}$ & $\mathrm{COH}$ & & $\begin{array}{c}\text { CON } \\
\text { vs. HO }\end{array}$ & $\begin{array}{c}\mathrm{CON} \\
\text { vs. } \mathrm{COH}\end{array}$ & $\begin{array}{c}\mathrm{HO} \\
\text { vs. } \mathrm{COH}\end{array}$ \\
\hline \multicolumn{8}{|c|}{ Withers height $(\mathrm{cm})$} \\
\hline Day 1 & 76.0 & 75.1 & 75.2 & 0.74 & 0.67 & 0.70 & 0.99 \\
\hline Day 28 & 81.1 & 80.9 & 82.3 & 0.71 & 0.99 & 0.43 & 0.36 \\
\hline Day 56 & 89.4 & 88.1 & 87.8 & 0.85 & 0.51 & 0.38 & 0.97 \\
\hline Day 70 & 90.6 & 91.3 & 90.1 & 0.75 & 0.79 & 0.85 & 0.47 \\
\hline Day 190 & 109.6 & 110.9 & 109.5 & 0.90 & 0.57 & 0.99 & 0.53 \\
\hline \multicolumn{8}{|c|}{ Body length (cm) } \\
\hline Day 1 & 69.3 & 68.2 & 67.4 & 0.56 & 0.33 & 0.06 & 0.56 \\
\hline Day 28 & 79.1 & 76.8 & 77.7 & 1.04 & 0.28 & 0.62 & 0.82 \\
\hline Day 56 & 87.5 & 85.9 & 85.6 & 0.74 & 0.29 & 0.18 & 0.95 \\
\hline Day 70 & 91.5 & 90.6 & 90.5 & 1.02 & 0.80 & 0.77 & 0.99 \\
\hline Day 190 & 124.8 & 126.0 & 124.4 & 1.02 & 0.67 & 0.96 & 0.50 \\
\hline \multicolumn{8}{|c|}{ Heart girth $(\mathrm{cm})$} \\
\hline Day 1 & 80.1 & 80.5 & 79.9 & 0.54 & 0.88 & 0.96 & 0.75 \\
\hline Day 28 & 91.1 & 91.5 & 90.0 & 0.77 & 0.92 & 0.60 & 0.38 \\
\hline Day 56 & 100.4 & 101.1 & 100.5 & 1.29 & 0.93 & 0.99 & 0.93 \\
\hline Day 70 & 107.2 & 107.7 & 107.2 & 0.77 & 0.89 & 1.00 & 0.89 \\
\hline Day 190 & 144.1 & 145.5 & 143.8 & 1.43 & 0.75 & 0.99 & 0.67 \\
\hline \multicolumn{8}{|c|}{ Abdominal girth $(\mathrm{cm})$} \\
\hline Day 1 & 74.3 & 77.3 & 76.5 & 1.15 & 0.18 & 0.39 & 0.87 \\
\hline Day 28 & 85.9 & 86.0 & 85.3 & 0.98 & 0.99 & 0.89 & 0.85 \\
\hline Day 56 & 94.7 & 100.2 & 97.9 & 1.54 & 0.04 & 0.32 & 0.54 \\
\hline Day 70 & 119.9 & 123.8 & 123.0 & 1.34 & 0.12 & 0.25 & 0.90 \\
\hline Day 190 & 171.3 & 173.8 & 171.4 & 1.74 & 0.57 & 0.99 & 0.60 \\
\hline
\end{tabular}

${ }^{1}$ During the preweaning period (d 2-56), calves were offered concentrate only (CON), hay only (HO), or both concentrate and hay $(\mathrm{COH})$. After weaning, all calves were exposed to concentrate and hay (d 57-70), and then TMR was supplied from d 71 to 196.

(Heinrichs et al., 2005). A decrease in blood glucose with calf age may be attributed to a shift in source of energy fuel from glucose to VFA as the rumen becomes functional in calves (Hammon et al., 2002). Previous studies, in agreement with our study, reported that glucose level was similar among calves fed a different ratio of hay to grain during the milk-feeding stage (Hibbs et al., 1956; Fernández, 2012). However, when calves consumed only solid diet without milk, some researchers showed that a higher consumption of hay than concentrate would reduce glucose concentration (Fernández, 2012; Terré et al., 2013). In the current study, postweaning calves in the $\mathrm{COH}$ group consumed a higher ratio of hay to TS than the CON and $\mathrm{HO}$ groups during $\mathrm{d} 57$ to 70 , which could have resulted in a numerical decrease in glucose concentration $(3.62,3.78$, and $3.85 \mathrm{mmol} / \mathrm{L}$ for $\mathrm{COH}$, CON, and HO, respectively). At d 196, serum glucose was consistent between treatments, coinciding with the sorting data, probably due to a similar ratio of hay to concentrate consumed by calves.

Least squares means for ruminal $\mathrm{pH}$ and VFA are listed in Table 8. Most of the treatment differences were found before changing the feed presentation method. Calves previously exposed to concentrate had lower ru-

Table 7. Effect of early feed exposure on glucose $(\mathrm{mmol} / \mathrm{L})$ in calves $(\mathrm{n}=10$ females/treatment) before and after weaning off milk

\begin{tabular}{|c|c|c|c|c|c|c|c|}
\hline \multirow[b]{2}{*}{ Day } & \multicolumn{3}{|c|}{ Treatment $^{1}$} & \multirow[b]{2}{*}{ SEM } & \multicolumn{3}{|c|}{$P$-value } \\
\hline & $\mathrm{CON}$ & $\mathrm{HO}$ & $\mathrm{COH}$ & & $\begin{array}{c}\text { CON } \\
\text { vs. HO }\end{array}$ & $\begin{array}{c}\mathrm{CON} \\
\text { vs. } \mathrm{COH}\end{array}$ & $\begin{array}{c}\mathrm{HO} \\
\text { vs. } \mathrm{COH}\end{array}$ \\
\hline Day 28 & 6.79 & 6.81 & 6.33 & 0.34 & 0.99 & 0.60 & 0.59 \\
\hline Day 56 & 5.40 & 4.84 & 5.24 & 0.24 & 0.23 & 0.89 & 0.48 \\
\hline Day 70 & 3.78 & 3.85 & 3.62 & 0.16 & 0.95 & 0.77 & 0.59 \\
\hline Day 190 & 4.43 & 4.47 & 4.43 & 0.11 & 0.97 & 1.00 & 0.97 \\
\hline
\end{tabular}

${ }^{1}$ During the preweaning period (d 2-56), calves were offered concentrate only (CON), hay only (HO), or both concentrate and hay $(\mathrm{COH})$. After weaning, all calves were exposed to concentrate and hay $(\mathrm{d} 57-70)$, and then TMR was supplied from d 71 to 196. 
men $\mathrm{pH}$ at $\mathrm{d} 28$ and 56 (6.43 and 6.03, respectively) compared with calves exposed to hay $(6.85, P=0.03$ and 6.76, $P<0.01$, respectively) or both concentrate and hay $(6.87, P=0.03$ and $6.53, P=0.03$, respectively). Similarly, the CON group had comparatively higher total VFA $(73.7 \mathrm{mmol} / \mathrm{L})$ than the $\mathrm{HO}(51.0$

Table 8. Effect of early feed exposure on $\mathrm{pH}$ and VFA in calves $(\mathrm{n}=10$ females/treatment) before and after weaning off milk

\begin{tabular}{|c|c|c|c|c|c|c|c|}
\hline \multirow[b]{2}{*}{ Item } & \multicolumn{3}{|c|}{ Treatment $^{1}$} & \multirow[b]{2}{*}{ SEM } & \multicolumn{3}{|c|}{$P$-value } \\
\hline & $\mathrm{CON}$ & $\mathrm{HO}$ & $\mathrm{COH}$ & & $\begin{array}{c}\text { CON } \\
\text { vs. HO }\end{array}$ & $\begin{array}{c}\mathrm{CON} \\
\text { vs. } \mathrm{COH}\end{array}$ & $\begin{array}{c}\mathrm{HO} \\
\text { vs. } \mathrm{COH}\end{array}$ \\
\hline \multicolumn{8}{|l|}{ Day 28} \\
\hline $\mathrm{pH}$ & 6.43 & 6.85 & 6.87 & 0.12 & 0.03 & 0.03 & 0.99 \\
\hline Acetate $(\mathrm{mmol} / \mathrm{L})$ & 34.7 & 27.7 & 25.6 & 2.03 & 0.13 & 0.12 & 0.91 \\
\hline Propionate $(\mathrm{mmol} / \mathrm{L})$ & 23.4 & 13.2 & 14.2 & 1.67 & $<0.01$ & $<0.01$ & 0.89 \\
\hline Isobutyrate (mmol/L) & 2.20 & 2.22 & 1.95 & 0.13 & 0.99 & 0.40 & 0.34 \\
\hline Butyrate $(\mathrm{mmol} / \mathrm{L})$ & 6.28 & 3.68 & 4.13 & 0.77 & 0.05 & 0.13 & 0.91 \\
\hline Isovalerate $(\mathrm{mmol} / \mathrm{L})$ & 2.50 & 2.33 & 2.02 & 0.23 & 0.87 & 0.35 & 0.64 \\
\hline Valerate $(\mathrm{mmol} / \mathrm{L})$ & 4.59 & 1.94 & 1.98 & 0.58 & $<0.01$ & $<0.01$ & 0.99 \\
\hline Total VFA $(\mathrm{mmol} / \mathrm{L})$ & 73.7 & 51.0 & 49.9 & 9.67 & 0.04 & 0.27 & 0.99 \\
\hline \multicolumn{8}{|l|}{ Day 56} \\
\hline $\mathrm{pH}$ & 6.03 & 6.76 & 6.53 & 0.14 & $<0.01$ & 0.03 & 0.43 \\
\hline Acetate $(\mathrm{mmol} / \mathrm{L})$ & 58.1 & 56.9 & 53.9 & 3.52 & 0.97 & 0.62 & 0.83 \\
\hline Propionate (mmol/L) & 38.7 & 22.2 & 30.1 & 3.21 & $<0.01$ & 0.15 & 0.21 \\
\hline Isobutyrate $(\mathrm{mmol} / \mathrm{L})$ & 1.73 & 1.47 & 1.52 & 0.13 & 0.35 & 0.49 & 0.97 \\
\hline Butyrate $(\mathrm{mmol} / \mathrm{L})$ & 16.8 & 14.3 & 12.8 & 1.68 & 0.55 & 0.19 & 0.80 \\
\hline Isovalerate $(\mathrm{mmol} / \mathrm{L})$ & 2.79 & 2.04 & 2.14 & 0.34 & 0.28 & 0.37 & 0.98 \\
\hline Valerate $(\mathrm{mmol} / \mathrm{L})$ & 8.62 & 4.48 & 4.18 & 1.24 & 0.06 & 0.04 & 0.98 \\
\hline Total VFA (mmol/L) & 126.7 & 101.4 & 104.6 & 9.66 & 0.17 & 0.25 & 0.97 \\
\hline \multicolumn{8}{|l|}{ Day 58} \\
\hline $\mathrm{pH}$ & 6.49 & 6.22 & 7.03 & 0.21 & 0.65 & 0.20 & 0.04 \\
\hline Acetate $(\mathrm{mmol} / \mathrm{L})$ & 44.0 & 63.3 & 39.6 & 5.95 & 0.08 & 0.45 & $<0.01$ \\
\hline Propionate (mmol/L) & 31.1 & 33.2 & 24.8 & 4.96 & 0.91 & 0.43 & 0.32 \\
\hline Isobutyrate $(\mathrm{mmol} / \mathrm{L})$ & 1.79 & 1.83 & 1.48 & 0.24 & 0.98 & 0.43 & 0.34 \\
\hline Butyrate $(\mathrm{mmol} / \mathrm{L})$ & 16.7 & 16.1 & 9.52 & 2.94 & 0.98 & 0.07 & 0.09 \\
\hline Isovalerate $(\mathrm{mmol} / \mathrm{L})$ & 1.97 & 1.82 & 1.29 & 0.26 & 0.83 & 0.05 & 0.15 \\
\hline Valerate $(\mathrm{mmol} / \mathrm{L})$ & 11.8 & 5.86 & 3.35 & 3.14 & 0.17 & 0.05 & 0.61 \\
\hline Total VFA (mmol/L) & 107.4 & 122.1 & 80.0 & 17.9 & 0.66 & 0.37 & 0.08 \\
\hline \multicolumn{8}{|l|}{ Day 63} \\
\hline $\mathrm{pH}$ & 5.93 & 5.59 & 5.91 & 0.15 & 0.22 & 0.99 & 0.26 \\
\hline Acetate $(\mathrm{mmol} / \mathrm{L})$ & 62.9 & 76.9 & 65.6 & 8.27 & 0.47 & 0.97 & 0.61 \\
\hline Propionate $(\mathrm{mmol} / \mathrm{L})$ & 40.0 & 47.2 & 43.4 & 7.00 & 0.75 & 0.94 & 0.92 \\
\hline Isobutyrate (mmol/L) & 1.80 & 1.50 & 1.27 & 0.23 & 0.64 & 0.27 & 0.77 \\
\hline Butyrate $(\mathrm{mmol} / \mathrm{L})$ & 23.5 & 25.7 & 16.2 & 7.15 & 0.84 & 0.64 & 0.28 \\
\hline Isovalerate $(\mathrm{mmol} / \mathrm{L})$ & 2.64 & 1.86 & 1.34 & 0.32 & 0.24 & 0.03 & 0.50 \\
\hline Valerate $(\mathrm{mmol} / \mathrm{L})$ & 16.6 & 10.52 & 7.95 & 2.82 & 0.07 & $<0.01$ & 0.52 \\
\hline Total VFA (mmol/L) & 147.5 & 163.7 & 135.8 & 18.4 & 0.81 & 0.90 & 0.55 \\
\hline \multicolumn{8}{|l|}{ Day 70} \\
\hline $\mathrm{pH}$ & 5.59 & 5.44 & 5.84 & 0.10 & 0.54 & 0.16 & 0.01 \\
\hline Acetate $(\mathrm{mmol} / \mathrm{L})$ & 65.7 & 72.4 & 59.3 & 3.62 & 0.40 & 0.43 & 0.04 \\
\hline Propionate (mmol/L) & 49.9 & 64.0 & 53.67 & 4.96 & 0.13 & 0.85 & 0.32 \\
\hline Isobutyrate $(\mathrm{mmol} / \mathrm{L})$ & 0.94 & 0.80 & 1.03 & 0.14 & 0.76 & 0.90 & 0.49 \\
\hline Butyrate $(\mathrm{mmol} / \mathrm{L})$ & 20.7 & 22.2 & 18.8 & 2.73 & 0.93 & 0.87 & 0.66 \\
\hline Isovalerate $(\mathrm{mmol} / \mathrm{L})$ & 1.47 & 0.97 & 1.49 & 0.26 & 0.36 & 0.99 & 0.33 \\
\hline Valerate $(\mathrm{mmol} / \mathrm{L})$ & 6.66 & 12.4 & 7.52 & 1.89 & 0.09 & 0.94 & 0.18 \\
\hline Total VFA $(\mathrm{mmol} / \mathrm{L})$ & 145.5 & 172.8 & 141.8 & 10.1 & 0.15 & 0.96 & 0.09 \\
\hline \multicolumn{8}{|l|}{ Day 190} \\
\hline $\mathrm{pH}$ & 6.54 & 6.70 & 6.78 & 0.12 & 0.57 & 0.30 & 0.87 \\
\hline Acetate $(\mathrm{mmol} / \mathrm{L})$ & 58.4 & 48.4 & 52.3 & 4.42 & 0.25 & 0.61 & 0.80 \\
\hline Propionate $(\mathrm{mmol} / \mathrm{L})$ & 23.8 & 17.9 & 21.4 & 1.77 & 0.06 & 0.59 & 0.36 \\
\hline Isobutyrate $(\mathrm{mmol} / \mathrm{L})$ & 1.75 & 1.74 & 1.79 & 0.11 & 0.46 & 0.74 & 0.90 \\
\hline Butyrate $(\mathrm{mmol} / \mathrm{L})$ & 12.2 & 10.6 & 11.8 & 1.09 & 0.55 & 0.96 & 0.72 \\
\hline Isovalerate $(\mathrm{mmol} / \mathrm{L})$ & 2.32 & 2.15 & 2.30 & 0.23 & 0.88 & 0.99 & 0.90 \\
\hline Valerate $(\mathrm{mmol} / \mathrm{L})$ & 1.85 & 1.68 & 1.98 & 0.20 & 0.82 & 0.90 & 0.55 \\
\hline Total VFA (mmol/L) & 100.4 & 82.6 & 91.6 & 6.02 & 0.12 & 0.73 & 0.84 \\
\hline
\end{tabular}

${ }^{1}$ During the preweaning period (d 2-56), calves were offered concentrate only (CON), hay only (HO), or both concentrate and hay $(\mathrm{COH})$. After weaning, all calves were exposed to concentrate and hay (d 57-70), and then TMR was supplied from d 71 to 196. 
$\mathrm{mmol} / \mathrm{L}, P=0.03)$ and $\mathrm{COH}(49.9 \mathrm{mmol} / \mathrm{L}, P=0.27)$ groups at d 28, mainly due to the higher levels of acetate, propionate, butyrate, and valerate. At d 56, the calves offered only concentrate early in life had lower rumen $\mathrm{pH}$ and higher propionate compared with those fed hay only.

Although DMI was similar between groups, it was apparent that calves exposed solely to concentrate before weaning experienced greater rumen fermentation as shown by higher amounts of VFA and a lower rumen $\mathrm{pH}$. In line with the present results, most studies showed that including forage in the diet of young calves can increase rumen pH (Thomas and Hinks, 2010; Mirzaei et al., 2015; Nemati et al., 2016), probably because the forage diet increases ruminating and chewing activity and hence salivation (Nemati et al., 2016). However, in contrast to previous studies (Coverdale et al., 2004; Nemati et al., 2016), ruminal VFA in calves fed only concentrate increased compared with that in calves fed only hay or concentrate and hay. Lack of differences in the aforementioned experiments might be due to the limited forage consumption by the calves. Coverdale et al. (2004) and Nemati et al. (2016) compared the VFA concentration between animals fed only concentrate and concentrate plus a fixed proportion of hay. They added 15 and $25 \%$ of hay in the diet, respectively, which was much lower than our $\mathrm{HO}(100 \%)$ and $\mathrm{COH}$ (free choice, $42 \%$ ) groups.

Immediately following transition to the free-choice diet, an independent and diverse variation rapidly occurred in each treatment on $\mathrm{d} 58$. A treatment $\times$ time effect among samples on d 56 and 58 was found in $\mathrm{pH}$ $(P=0.04)$ and propionate $(P=0.04)$. With both concentrate and hay offered to calves, rumen $\mathrm{pH}$ increased by 0.43 unit from d 56 to 58 in CON and decreased by 0.54 unit in HO. Propionate concentration decreased by $7.6 \mathrm{mmol} / \mathrm{L}$ in CON (from 38.7 to $31.1 \mathrm{mmol} / \mathrm{L}$ ) and increased by $11.0 \mathrm{mmol} / \mathrm{L}$ in $\mathrm{HO}$ (from 22.2 to 33.2 $\mathrm{mmol} / \mathrm{L})$. These changes could be attributed to hay consumption in CON and concentrate consumption in $\mathrm{HO}$ when both types of feed were introduced to calves postweaning. Previous studies demonstrated that concentrate intake improved the growth and proliferation of starch fermenters in the rumen, which resulted in increased propionate production (Stobo et al., 1966; Dijkstra, 1994). Inclusion of hay in the diet is likely to promote salivary secretion and flow to the rumen (Ackeren et al., 2009), which in turn might increase the rumen $\mathrm{pH}$ and lower propionate. The results indicated that along with the changes in diet components, rumen microbiota could have also responded, immediately altering the rumen fermentation (Calsamiglia et al., 2008). Rumen $\mathrm{pH}$ decreased and VFA concentration increased as the calves grew older, which was consistent with the findings of Coverdale et al. (2004). The increase in feed intake may have caused the observed changes in VFA concentration and rumen $\mathrm{pH}$ postweaning.

After $2 \mathrm{~d}$ of transition to a free-choice diet (on d 58), numerically higher rumen $\mathrm{pH}$ and lower total VFA were exhibited in $\mathrm{COH}$ calves $(\mathrm{pH}=7.03$, total $\mathrm{VFA}=80.0$ mmol/L) compared with $\mathrm{CON}(\mathrm{pH}=6.49, P=0.20$; total $\mathrm{VFA}=107.4 \mathrm{mmol} / \mathrm{L}, P=0.37)$ and $\mathrm{HO}(\mathrm{pH}=$ $6.22, P=0.04$; total $\mathrm{VFA}=122.1 \mathrm{mmol} / \mathrm{L}, P=0.08)$ calves. Two weeks postweaning (at d 70), numerically higher rumen $\mathrm{pH}$ also persisted in $\mathrm{COH}$ calves (5.84) compared with CON $(5.59, P=0.16)$ and $\mathrm{HO}(\mathrm{pH}$ $=5.44, P=0.01)$ calves. This could be attributed to the higher proportion of hay to TS feed in calves exposed to concentrate and hay early in life. At d 190, we tested the hypothesis that EFE could have long-term effects later in life. No treatment effects were found in rumen $\mathrm{pH}$ and VFA concentration, probably because the numerical changes in sorting patterns could not affect changes in rumen fermentation (Coverdale et al., 2004). These results suggest that early feed experiences may have the capacity to regulate rumen fermentation in the short term, but over the long term the effects fade away, especially as a result of the sorting behavior in heifers. A previous study demonstrated that there exists an association between sorting behavior and rumen $\mathrm{pH}$ in adult dairy cows (Devries et al., 2008). The authors reported that cows that tended to sort against long particles had the lowest maximum rumen $\mathrm{pH}$. Few studies have attempted to explore similar relationships in calves and heifers. Thus, more research is required to conclusively define whether and how feed preference (sorting behavior) affects rumen fermentation in calves and heifers in different age groups.

\section{CONCLUSIONS}

Early feed type exposure had a varying effect on calf and heifer performance during the first $27 \mathrm{wk}$ of life. In the milk-feeding period, feed intake, BW, ADG, blood glucose, and structural growth were similar before and after weaning, but feed preference and rumen fermentation differed. Hay consumption was higher only on the first day postweaning in calves fed only hay preweaning compared with calves exposed to concentrate. However, provision of both concentrate and hay early in life resulted in greater intake of hay and a higher ratio of hay to TS feed than provision of either concentrate or hay only, giving rise to a numerically higher rumen $\mathrm{pH}$ and lower VFA and blood glucose postweaning (during d 57-70). Furthermore, exposure to a diet of both concentrate and hay early in life could improve the ability of calves to sort for long particles. Therefore, our results suggested that EFE could influence choice of feed im- 
mediately after weaning and may have a long-lasting effect on feed preference in heifers later in life.

\section{ACKNOWLEDGMENTS}

We are grateful to Modern Farming Co. Ltd. (Baoji, Shanxi, P. R. China) for allowing us to use their animals and facilities. We also appreciate the help and technical assistance received from their staff and students from China Agricultural University (Beijing), who included Chunlin Han, Xiaoyong Li, Jie Wang, Boyi Sun, Yan Zhang, Shaowei Li, Bendong Zhang, Jianhong Zhai, Dongnian Zhou, Feirang Wang, Sihang A, Hui Yan, Gaowa Naren, Shuai Huang, Jingjun Wang, Yanfang Liu, Jing Ning, Jingjing Liu, Yan Yu, and Guoqing Sun. This work was supported by the China Agriculture Research System (CARS-36; Beijing, China).

\section{REFERENCES}

Ackeren, C. V., H. Steingass, K. Hartung, R. Funk, and W. Drochner 2009. Effect of roughage level in a total mixed ration on feed intake, ruminal fermentation patterns and chewing activity of earlyweaned calves with ad libitum access to grass hay. Anim. Feed Sci. Technol. 153:48-59.

Alugongo, G. M., J. X. Xiao, Y. H. Chung, S. Z. Dong, S. L. Li, I. Yoon, Z. H. Wu, and Z. J. Cao. 2017. Effects of Saccharomyces cerevisiae fermentation products on dairy calves: Performance and health. J. Dairy Sci. 100:1189-1199.

AOAC International. 1995. Official Methods of Analysis. Vol. I 16th ed. AOAC Int., Arlington, VA.

Calsamiglia, S., P. W. Cardozo, A. Ferret, and A. Bach. 2008. Changes in rumen microbial fermentation are due to a combined effect of type of diet and pH. J. Anim. Sci. 86:702-711.

Castells, L., A. Bach, A. Aris, and M. Terré. 2013. Effects of forage provision to young calves on rumen fermentation and development of the gastrointestinal tract. J. Dairy Sci. 96:5226-5236.

Cooke, L., and A. Fildes. 2011. The impact of flavour exposure in utero and during milk feeding on food acceptance at weaning and beyond. Appetite 57:808-811.

Costa, J. H. C., N. A. Adderley, D. M. Weary, and M. A. G. V. Keyserlingk. 2016. Short communication: Effect of diet changes on sorting behavior of weaned dairy calves. J. Dairy Sci. 99:5635-5639.

Costa, J. H. C., R. R. Daros, M. A. G. V. Keyserlingk, and D. M Weary. 2014. Complex social housing reduces food neophobia in dairy calves. J. Dairy Sci. 97:7804-7810.

Coverdale, J. A., H. D. Tyler, Q. J. Rd, and J. A. Brumm. 2004. Effect of various levels of forage and form of diet on rumen development and growth in calves. J. Dairy Sci. 87:2554-2562.

DeVries, T. J., K. A. Beauchemin, and M. A. von Keyserlingk. 2007. Dietary forage concentration affects the feed sorting behavior of lactating dairy cows. J. Dairy Sci. 90:5572-5579.

DeVries, T. J., F. Dohme, and K. A. Beauchemin. 2008. Repeated ruminal acidosis challenges in lactating dairy cows at high and low risk for developing acidosis: Feed sorting. J. Dairy Sci. 91:3958 3967.

DeVries, T. J., and M. A. von Keyserlingk. 2009. Short communication: Feeding method affects the feeding behavior of growing dairy heifers. J. Dairy Sci. 92:1161-1168.

DeVries, T. J., M. A. von Keyserlingk, and K. A. Beauchemin. 2005. Frequency of feed delivery affects the behavior of lactating dairy cows. J. Dairy Sci. 88:3553-3562.

Dijkstra, J. 1994. Production and absorption of volatile fatty acids in the rumen. Livest. Prod. Sci. 39:61-69.
Erwin, E. S., G. J. Marco, and E. M. Emery. 1961. Volatile fatty acid analyses of blood and rumen fluid by gas chromatography. J. Dairy Sci. 44:1768-1771.

Fernández, H. T. 2012. Growth, blood metabolites and hormones in calves fed diets with different amounts of energy and protein during the pre- or post-weaning periods. Afr. J. Agric. Res. 7:37393746.

Gao, X., and M. Oba. 2014. Relationship of severity of subacute ruminal acidosis to rumen fermentation, chewing activities, sorting behavior, and milk production in lactating dairy cows fed a highgrain diet. J. Dairy Sci. 97:3006-3016.

Ginane, C., R. Baumont, and A. Favreaupeigné. 2011. Perception and hedonic value of basic tastes in domestic ruminants. Physiol. Behav. 104:666-674.

Greter, A. M., T. J. Devries, and M. A. von Keyserlingk. 2008. Nutrient intake and feeding behavior of growing dairy heifers: Effects of dietary dilution. J. Dairy Sci. 91:2786-2795.

Hammon, H. M., G. Schiessler, A. Nussbaum, and J. W. Blum. 2002 Feed intake patterns, growth performance, and metabolic and endocrine traits in calves fed unlimited amounts of colostrum and milk by automate, starting in the neonatal period. J. Dairy Sci 85:3352-3362.

Harris, G. 2008. Development of taste and food preferences in children. Curr. Opin. Clin. Nutr. Metab. Care 11:315-319.

Hart, K. D., B. W. Mcbride, T. F. Duffield, and T. J. Devries. 2014. Effect of frequency of feed delivery on the behavior and productivity of lactating dairy cows. J. Dairy Sci. 97:1713-1724.

Heinrichs, A. J., K. E. Lesmeister, and P. C. Garnsworthy. 2005. Rumen development in the dairy calf. Pages 53-65 in Proc. Calf and Heifer Rearing: Principles of Rearing the Modern Dairy Heifer from Calf to Calving. Nottingham Easter School in Agricultural Science, Nottingham, UK.

Hibbs, J. W., H. R. Conrad, W. D. Pounden, and N. Frank. 1956. A high roughage system for raising calves based on early development of rumen function. 6. Influence of hay to grain ratio on calf performance, rumen development, and certain blood changes. J. Dairy Sci. 39:171-179.

Imani, M., M. Mirzaei, B. Baghbanzadehnobari, and M. H. Ghaffari. 2017. Effects of forage provision to dairy calves on growth performance and rumen fermentation: A meta-analysis and meta-regression. J. Dairy Sci. 100:1136-1150.

Khan, M. A., H. J. Lee, W. S. Lee, H. S. Kim, K. S. Ki, T. Y. Hur, G. H. Suh, S. J. Kang, and Y. J. Choi. 2007. Structural growth, rumen development, and metabolic and immune responses of Holstein male calves fed milk through step-down and conventional methods. J. Dairy Sci. 90:3376-3387.

Khan, M. A., D. M. Weary, and M. A. von Keyserlingk. 2011. Hay intake improves performance and rumen development of calves fed higher quantities of milk. J. Dairy Sci. 94:3547-3553.

Kononoff, P. J., A. J. Heinrichs, and D. R. Buckmaster. 2003. Modification of Penn State forage and total mixed ration particle separator and the effects of moisture content on its measurements. J. Dairy Sci. 86:1858-1863.

Leonardi, C., and L. E. Armentano. 2003. Effect of quantity, quality, and length of alfalfa hay on selective consumption by dairy cows. J. Dairy Sci. 86:557-564.

Leonardi, C., F. Giannico, and L. E. Armentano. 2005. Effect of water addition on selective consumption (sorting) of dry diets by dairy cattle. J. Dairy Sci. 88:1043-1049.

Maulfair, D. D., M. Fustini, and A. J. Heinrichs. 2011. Effect of varying total mixed ration particle size on rumen digesta and fecal particle size and digestibility in lactating dairy cows. J. Dairy Sci. 94:3527-3536.

Miller-Cushon, E. K., R. Bergeron, K. E. Leslie, G. J. Mason, and T. J. Devries. 2013. Effect of early exposure to different feed presentations on feed sorting of dairy calves. J. Dairy Sci. 96:4624-4633.

Miller-Cushon, E. K., and T. J. DeVries. 2011. Effect of early feed type exposure on diet-selection behavior of dairy calves. J. Dairy Sci. 94:342-350. 
Miller-Cushon, E. K., and T. J. DeVries. 2017. Feed sorting in dairy cattle: Causes, consequences, and management. J. Dairy Sci. 100:4172-4183.

Mirzaei, M., M. Khorvash, G. R. Ghorbani, M. Kazemi-Bonchenari, A. Riasi, A. Nabipour, and V. D. B. Jj. 2015. Effects of supplementation level and particle size of alfalfa hay on growth characteristics and rumen development in dairy calves. J. Anim. Physiol. Anim. Nutr. (Berl.) 99:553-564.

Nasrollahi, S. M., G. R. Ghorbani, M. Khorvash, and W. Z. Yang. 2014. Effects of grain source and marginal change in lucerne hay particle size on feed sorting, eating behaviour, chewing activity, and milk production in mid-lactation Holstein dairy cows. J. Anim. Physiol. Anim. Nutr. (Berl.) 98:1110-1116.

Nemati, M., H. Amanlou, M. Khorvash, M. Mirzaei, B. Moshiri, and M. H. Ghaffari. 2016. Effect of different alfalfa hay levels on growth performance, rumen fermentation, and structural growth of Holstein dairy calves. J. Anim. Sci. 94:1141-1148.

Nombekela, S. W., M. R. Murphy, H. W. Gonyou, and J. I. Marden. 1994. Dietary preferences in early lactation cows as affected by primary tastes and some common feed flavors. J. Dairy Sci. 77:23932399 .
Overvest, M. A., R. Bergeron, D. B. Haley, and T. J. Devries. 2016. Effect of feed type and method of presentation on feeding behavior, intake, and growth of dairy calves fed a high level of milk. J. Dairy Sci. 99:317-327.

Stobo, I. J. F., J. H. B. Roy, and H. J. Gaston. 1966. Rumen development in the calf. 1 . The effect of diets containing different proportions of concentrates to hay on rumen development. Br. J. Nutr. 20:171-188.

Suarez-Mena, F. X., T. M. Hill, C. M. Jones, and A. J. Heinrichs, 2016. Review: Effect of forage provision on feed intake in dairy calves. Prof. Anim. Sci. 32:383-388.

Terré, M., E. Pedrals, A. Dalmau, and A. Bach. 2013. What do preweaned and weaned calves need in the diet: A high fiber content or a forage source? J. Dairy Sci. 96:5217-5225.

Thomas, D. B., and C. E. Hinks. 2010. The effect of changing the physical form of roughage on the performance of the early-weaned calf. Anim. Prod. 35:375-384

Wijayasinghe, M. S., N. E. Smith, and R. L. Baldwin. 1984. Growth, health, and blood glucose concentrations of calves fed high-glucose or high-fat milk replacers. J. Dairy Sci. 67:2949-2956. 